\title{
Japan's Rational Choice in Developing the Halal Industry
}

\author{
${ }^{1}$ NENENG KONETY, ${ }^{2}$ SAVITRI ADITIANY, ${ }^{3}$ NURFARAH NIDATYA \\ ${ }^{12}$ Universitas Padjadjaran, Jl. Raya Bandung-Sumedang Km.21, Indonesia \\ ${ }^{3}$ Universiti Utara Malaysia, Alumni Ghazalie Shafie Graduate School, Sintok, 06010 Bukit Kayu \\ Hitam, Kedah, Malaysia \\ email: ${ }^{1}$ neneng.konety@unpad.ac.id² savitri.aditiany@unpad.ac.id ${ }^{3}$ nurfarahnidatya@gmail.com
}

\begin{abstract}
Nowadays, the halal industry has become a new trend in various regions of the world, including East Asia, which the majority of the population is not Muslim. This research will focus on the development of the halal industry in various segments and the reasons that underlie one of the Muslim minority countries in the East Asia Region, namely Japan, in developing the halal industry as a rational choice for its country. This study uses a qualitative method, where data are collected from semistructured interviews and literature studies. The results of this study indicate that for non-Muslim countries, particularly Japan, to develop the Halal industry as a rational choice are due to several reasons, namely globalization, the fall of Japanese yen, demographics, and bilateral relations between Japan and neighboring countries. In the end, some of these reasons stimulate Japan to take action to boost its economy and gain the most beneficial option, one of which is by developing the halal industry to reach out to the Muslim market.
\end{abstract}

Keywords: halal industry, rational choice, halal certification.

\section{Introduction}

Based on etymology, the word 'halal' refers to the meaning of what is allowed and can be done because it is free or not bound by the provisions that prohibit it. These days, Halal emerges not only as a powerful market entity, but also as a growing world phenomenon for both Muslims and nonMuslims (Akim et al., 2019). The "halal" label on a product not only guarantees that the product is allowed to be consumed by Muslims, but has also become a global symbol for quality assurance and lifestyle choices (Akim et al., 2019).

The population growth rate of Muslims worldwide is $3 \%$ per year with an estimated total of 1.8 billion Muslims and this number is predicted to increase to 2.2 billion in 2030 (Kementerian Perencanaan Pembangunan Nasional, 2018). This creates promising market segmentation for producers, therefore many companies are finally interested in using halal standards for their products with the aim of attracting Muslim consumers to purchase their products.
State of the Global Islamic Economy Report 2018 estimated that the value of spending on halal food, beverages and lifestyles sectors will exceed USD 3 trillion limit by the end of 2023 (Hasan et al., 2018) shariah-based principles, to halal food that height- ens trust between producer and consumer - from the farm to the fork. Blossom Finance is a perfect example, with its blockchain solution to help SMEs raise sukuk finance. With 1.8 billion Muslims, and Muslim spend estimated at US $\$ 2.1$ trillion in 2017, the Islamic economy continues its steady growth. But there is significant scope for growth and maturity in the Islamic economy, with a mere US\$745 million in disclosed private equity investments over three years, far less than the almost US $\$ 595$ billion in private equity and venture capital investments that occurred globally in 2017. While more government backing is needed in certain segments of the Islamic economy, at the same time there was a more nuanced focus on the necessary steps to take the Islamic economy further, especially regulations. We are also seeing certain

Received: December 18, 2020, Revision: March 08, 2021, Accepted: June 11, 2021

Print ISSN: 0215-8175; Online ISSN: 2303-2499. DOI: https://doi.org/10.29313/mimbar.v37il.7057

Accredited Sinta 2 based on the decree No.10/E/KPT/2019 until 2024. Indexed by DOAJ, Sinta, Garuda, Crossreff, Dimensions 
countries come out as leaders, notably the $\mathrm{UAE}$, Malaysia and, to a lesser degree, Saudi Arabia and Indonesia. This report estimates that global Muslim spend across life- style sectors was US\$2.1 trillion in 2017, while the Islamic finance sector has US $\$ 2.4$ trillion in total assets. Food and beverage leads Muslim spend by category at US $\$ 1.3$ trillion, followed by clothing and apparel at US $\$ 270$ billion, media and entertainment at US $\$ 209$ billion, travel at US\$177 billion, and spending on pharmaceuticals and cosmetics at US $\$ 87$ billion and US\$61 billion respectively. The Islamic economy has shown it is in tune with the latest developments in technology and investment. Companies have adopted blockchain technology for payments, to confirm halal compliance, or track food, cosmetics and pharmaceuti- cal products from the manufacturing facility to the retailer. In Islamic finance, blockchain and automation is expanding access to financial services. Smart technologies are being incorporated into clothing, such as the smart hijab, to GPS systems that show the closest prayer spaces. Equally, investment is taking place in artifi- cial intelligence (AI. Muslim population in the world is expected to spend more than USD 274 billion by the end of 2023 on tourism (Hasan et al., 2018). Consumption of womenswear in the global fashion industry was estimated to reach more than USD 621 billion in 2014 with an increase of $12 \%$ within five years (Utami et al., 2019). The halal industry segmentation is no longer limited to sectors that are related to halal food and restaurants but also growing in other sectors such as cosmetics and halal fashion.

Halal trend currently become a new term called 'halal lifestyle', which shows that 'halal' has increasingly become a person's preference. The fact that 'halal' is scientifically proven as a product standard with healthy and clean quality influences consumers of halal products not exclusively addressed to Muslims. This is the reason that non-Muslim countries, for example in the East Asia Region, participate in developing the Halal industry.

The halal industry is becoming a trend and has expanded in various regions of the world, including the East Asia region. In South Korea, for example, popular culture is the reason to have connections with the Muslim world. Through popular culture, South Korea has attracted many foreign tourists, including citizens from Muslim countries
(Deniar \& Effendi, 2019). Halal industry has also attracted much attention from Chinese government. According to recent studies by food and agribusiness experts, Farrelly and Mitchell, the achievement of China halal industry in 2021 is expected to reach US\$1.9 trillion (Damhuri, 2018). In Taiwan, there are approximately 200 halalcertified restaurants which indicates that the government also concern about Halal food. In 2016, the New Southbound Policy (NSP) was initiated by the President of Taiwan, Tsai Ing-wen, in which one of the points is closely related to the Halal industry (Anwar, 2019).

There is no exception regarding the development of the halal industry in Japan. In recent years, Japanese government has also made efforts to develop the halal industry by offering halal tourism facilities. Halal-certified restaurants continue to grow; even numerous halal-certified cosmetic products continue to emerge in Japan.

One of the most interesting facts about Japan's situation is the strategy or efforts from Japanese government to develop the halal industry even though the Muslim population in Japan is relatively few in number. Japan is a country that has the least Muslim population compared to three other East Asian countries. In 2010, Japan's Muslim population only reach 126,836 people and it is estimated that in 2020 the Muslim population in Japan is only $0.1 \%$, when compared to China which the percentage of Muslim population is $4.02 \%$, and South Korea with a percentage of $0.5 \%$ (Kettani, 2010). Considering the situation, this research focused on the development of the halal industry, especially in Japan.

The halal industry is one of the interesting topics discussed in various disciplinary approaches, including in International Relations Studies. Previous studies mentioned that there are various factor that underlies the development of global halal industry which trigger this industry to grow rapidly (Azam \& Abdullah, 2020); (Murti, 2017). First, Muslim population is huge and growing rapidly. Second, the economy growth that has an impact on increasing customer purchases among Muslim consumers. Finally, the emergence of potential halal market and halal industry players in non-Muslim countries, as well as the era of modernization that reinforces new trends which appearing as halal and Islamic lifestyles in global trade. 
The halal industry in non-Muslim countries, such as Thailand, Korea, and Japan, generally comprises halal food segmentation (Mathew et al., 2014)(Mohd Nawawi et al., 2019). It is discovered that halal consumption becomes a new trend. This trend is as a reaction from Muslim community to assure food and other products are suitable for consumption by Muslims who visit a country, and at the same time broaden economic opportunities for the country.

The Halal food business in Japan is known as very potential but there are some issues, particularly for small industries in obtaining halal certification (Ismail, 2017); (Yusof \& Shutto, 2014)(Kitayama et al., 2018). The halal integrity assurance for food in Japan has to pass through the challenges process and still has multiple obstacles.

There were many studies that discussed about halal food as one segment of halal industry in non-Muslim countries, including Japan. However, it is perceived that the Japanese government consistently to continuously develops the halal industry in its country. This is described in Mutiara \& Dian's research (2019), which stated that Japan is not a Muslim-majority country but has a specific strategy to become a Muslimfriendly country and determined to compete among Muslim country markets (Mutiara \& Dian, 2019).

In deciding to develop its halal industry to become a Muslim-friendly country as a rational choice, Japanese government certainly has a reason that underlie this choice. In political economy, the rational choice theory has a place due to Kenneth Arrow. In general, the concept of rationality in new political economy is related to the concepts of preference, belief, opportunity and action (Deliarnov, 2006). Preferences are closely related to choices; beliefs are related to individuals acting based on beliefs about the causal structure of the real world; opportunity related to resources and constraints; and action related to the choice that is finally achieved. Based on this concept, it can be explained that rational choice theory intends to decision making which leads to a beneficial choice.

The growing halal industry segmentation in Japan is not only limited to halal food trend, but also in other fields. This phenomenon explains that there are reasons that influence the development of Halal industry in Japan as Japan's rational choice in facing the global market. This study aims to explain the development of the Japanese halal industry in several segments, namely halal food, halal restaurants, halal cosmetics and halal fashion, and understand the reasons of developing the halal industry in Japan as a Muslim minority country with a low percentage of Muslim population in the East Asia Region.

\section{Research Methodology}

This study used a qualitative method which aimed to explain the development of halal industry in East Asia, especially Japan. In addition, this study also investigated further rational factors that underlie the Japanese society and government to participate in developing the halal industry in their country which includes segmentation of halal food, restaurants, halal cosmetics and halal fashion. This phenomenon is interesting considering that Japan is not a country with a majority Muslim population.

This study collected primary and secondary data in order to assess the focus and locus of research. Primary data was collected by interview method. In determining the informants in this study, the researcher chose a purposive sampling technique. The purposive sampling technique is a sampling technique of data sources with certain considerations, which in this study was the assumption that the informants were considered as those who mastered and experienced in the development of Japanese Halal industry. Based on this description, the research subject for primary data is the Manager of Global Strategies Food Diversity. Inc (Halal Media Japan) who also oversees the Japanese Halal Gourmet service and the Japan Mosque Finder. These informants are determined based on mastery in the halal industry in Japan as a private sector which has a large role in pioneering the development of Japanese Halal industry and supports the Japanese government in providing consultation and information related to halal/Muslim friendly.

The next informants determined by the researchers were Japanese Muslims, Muslim foreign students in Japan, Muslim foreign workers in Japan, and Muslim tourists in Japan as the market share of the Japanese halal industry. As for the secondary data sources, they were obtained through literature study including books, journals, documents and 
written annual reports, official Japanese government reports which can be accessed through the official Japanese government website, as well as other websites related to this research.

The research instrument used in this study is the researcher itself with the assistance of an interview guide and several other technical equipments such as a recording device, camera, and field notes. Meanwhile, secondary data was collected through the process of studying literature on journals, documents, archives, and policies related to the halal industry.

\section{Results and Discussion}

\section{Japanese Halal Industry}

The halal industry in Japan was first emerged during the Japanese bubble economy in the 1980s, along with the increasing number of tourists from Muslim countries and grew significantly in the 1990s and it began to spread throughout Japan (Adidaya, 2016). According to a business observer, Yuswohady, this phenomenon is suspected to arise because the pattern of Muslim consumers who are increasingly concerned about the halal of a product has finally led to the phenomenon of the 'halal boom' or the explosion of products labeled as halal in the market. Furthermore, experts argue that the halal boom occurred with media support, which is an effective tool to introduce and disseminate the halal concept in various non-Muslim majority countries including Japan. (Sah, 2018).

As a Muslim minority country, Japan experienced a growing Muslim population during the bubble economy. Based on 2016 data, there were approximately 120,000 Muslims abroad and 10,000 Japanese Muslims living in Japan and are based in three major metropolitan areas (Tokyo, Chukyo and Kinki), Muslim networks have never stopped growing throughout Japan (Tanada, 2017).

\section{Halal Food and Restaurant}

Halal restaurants in Japan are growing rapidly. However, it is undeniable that there are many restaurants that do not provide halal or halal-certified menus, for example, as complained by Muslim foreign students who live in small cities (Budianti, 2020). However, referring to Japan's tourismoriented foreign policy, including the target market for Muslim tourists, gradually changes and progress in the availability of Muslimfriendly facilities are increasing. The official Japanese government website contains Muslim-friendly Japanese tourism guides such as muslim guide, jnto, several private travel reservation sites such as Voyagin, Halal Media Japan, Halal Gourmet, Halal in Japan, Japan Mosque Finder and Halal Navi Japan social media offering several lists of halal or Muslim friendly restaurants which is recognized as a helpful way in traveling comfortably by Muslim tourists (Hasni, 2020).

Table 1

Japanese Restaurant That Serves Halal Food and Halal Certified Restaurant

\begin{tabular}{lccc}
\hline Area & $\begin{array}{c}\text { Restaurant } \\
\text { Provides } \\
\text { Halal Food } \\
\text { (unit) }\end{array}$ & $\begin{array}{c}\text { Halal } \\
\text { Certified } \\
\text { Restau- } \\
\text { rant }\end{array}$ & $\begin{array}{c}\text { Total } \\
\text { (unit) }\end{array}$ \\
\hline Tokyo & 244 & 86 & 330 \\
Osaka & 53 & 17 & 70 \\
Kanagawa & 34 & 3 & 37 \\
Aichi & 34 & 6 & 40 \\
Kyoto & 38 & 21 & 59 \\
Fukuoka & 11 & 2 & 13 \\
Lokasi Lain & 272 & 47 & 319 \\
Total & $\mathbf{6 8 6}$ & $\mathbf{1 8 2}$ & $\mathbf{8 6 8}$ \\
\hline
\end{tabular}

Source: Halal-Gourmet Japan, 2020

Table 1 shows that halal-certified restaurants have reached a fairly high number, as well as restaurants that provide halal menus. This shows that Japan takes serious efforts to provide service convenience for Muslim people by supplying halal food and restaurants in various parts of Japan. Japan is one of the non-Muslim countries in the world that willing to present itself as a Muslimfriendly tourist destination. The increasing number of foreign tourists visiting Japan has encouraged the Japanese government to continuously improve its services, especially for Muslim tourists because Muslim tourists can easily spend money in Japan without worrying about halal/non-halal status (Hasni, 2020)

The availability of halal restaurants for Muslim tourists is regarded as important to encourage the satisfaction of Muslim tourists to travel to Japan (Hasni, 2020). With the number and distribution of halal restaurants and halal food in Japan as shown in table 1 that reaches 868 units, it certainly support 
the notion that Japan is a Muslim-friendly country. From the point of view of Muslims, eating halal food is a religious observance. On the other hand, from the Japanese point of view, they do not have any interest in Muslim teachings and halal itself; they are more interested in business opportunities that can be created from the needs of Muslims tourist for halal products in Japan (Adidaya, 2016).

\section{Halal Cosmetics}

Japan is also actively launching halal products other than food and beverages, such as cosmetics as listed in table 2 as some of halal industries that are being developed by Japan.

\section{Table 2}

\section{List of Japanese Halal Cosmetic} Products

\begin{tabular}{cl}
\hline No. & \multicolumn{1}{c}{ Product Name } \\
\hline 1. & Momo Hime \\
2. & Melati \\
3. & Blanc Elena \\
4. & H\&N cosmetic \\
5. & Hontou Tsubaki \\
6. & Halal Nail Tokyo \\
7. & Royal Cosmetic \\
8. & Mofid \\
9. & Newlogic.co \\
10. & Hiro japan.co \\
11. & Marna Cosmetic \\
12. & Plaisir \\
13. & Sakura Kokoro Skincare \\
\hline & Source: Researcher, 2020
\end{tabular}

In recent years, several Japanese companies have released their first halalcertified cosmetics. These products are not only sold in Japan, but also international markets. For example, as listed in table 2, Momo Hime, is one of the first halal cosmetic brands produced by a Japanese company called PBJ. This beauty product has been on sale since 2016 with the target customers of Muslims in Japan. However, it is not only limited to Muslims, this cosmetic product is also popular among non-Muslim consumers (Muslimah, 2016).

Halal cosmetics listed in table 2 generally include ingredients that are free of alcohol, free of surfactants, free of raw materials derived from pork, free of mineral oil and free of dyes, some of these products are made from plant or fruit extracts or are based on the concept of cosmetics vegan, so that these criteria are also useful for nonMuslim consumers who have special criteria in choosing cosmetics that are made from safe and high-quality ingredients.

As described in table 2, one of the Japanese companies that produce halal cosmetics is the Greato Corporation that launches cosmetic products with an Indonesian-language brand Melati. Its products received a halal certificate from the Japan Islamic Trust (JIT) in 2017. Also in 2017, JIT previously issued a halal certificate for the cosmetic brand Blanc Elena (Wahidati \& Sarinastiti, 2018).

\section{Halal Fashion}

The halal phenomenon has also entered other segments such as fashion industry. Halal fashion actually includes clothing that is usually worn by Muslim women or has long been known as Islamic clothing. In today fashion industry, the clothes usually worn by Muslim women also known as modest wear. Modest wear is based on religious teachings such as Islam, which aims to prevent the wearer as an object of sexual attention by blurring the silhouette of the body and being closed. However, this fashion trend is now enjoyed by many people around the world, including in Japan. The Japanese fashion market, however, is quite predictable as it is expected to grow to US\$72.72 billion by 2020 (Smith, 2017).

President and chief executive of the Japan Muslim Fashion Association (JMFA) Shinichi Orita mentioned that there is an optimism in the growth of Islamic fashion in Japan, considering the increment of interest in visiting Japan, especially through simplified visa regulations for countries with large Muslim populations such as Indonesia, Malaysia, and Thailand (Smith, 2017). Relating to the small number of Muslims in Japan, the successfulness of this strategy will depends on the acceptance and purchase by non-Muslim women. Although there are only few Muslim women in Japan, the environment for Muslims is steadily improving in Japan. In addition, the Japanese kimono has an affinity with 'Muslim fashion', as there is a traditional culture to cover the skin among Japanese people. It reflects that Japanese women's affinity with Muslim fashion is strong; their way of thinking is closer to Islamic teachings regarding proper attire (Smith, 2017). 
According to global strategies manager food diversity inc., there are several fashion companies that have produced Islamic clothing. Fashion companies such as Uniqlo in collaboration with Hana Tajima (a Japanese Muslim designer) launched clothing for Muslim women since July 2017 (Zulaikha, 2020). There is also a company called Watashi Japan LLC. This company produces Muslim women's head coverings (hijab) and cardigans from kimono material that decorated with Japanese motifs (Wahidati \& Sarinastiti, 2018).

\section{Japanese Halal Certification}

Currently, several Japanese food and cosmetic manufacturers are expanding their market to Southeast Asian countries. This situation leads to the necessity of label halal for export purposes, and Japanese manufacturers attempt to obtain halal certification. It indicates that halal certification become a crucial issue for Japan to penetrate the Southeast Asian market as well as the global Muslim market.

The halal certification system becomes an important part for confirming the halal status of a product. According to the private agency Food Diversity Inc., in order to sell their products to the Muslim market, Japanese companies must strive to obtain halal certification from various countries. In fact, obtaining halal certification is highly challenging because the requirements that must be met by companies are very strict.

As shown in figure 1 , there are two main ways to get halal certification in Japan. One of them is to apply directly to the inspection/ certification agency approved by the export

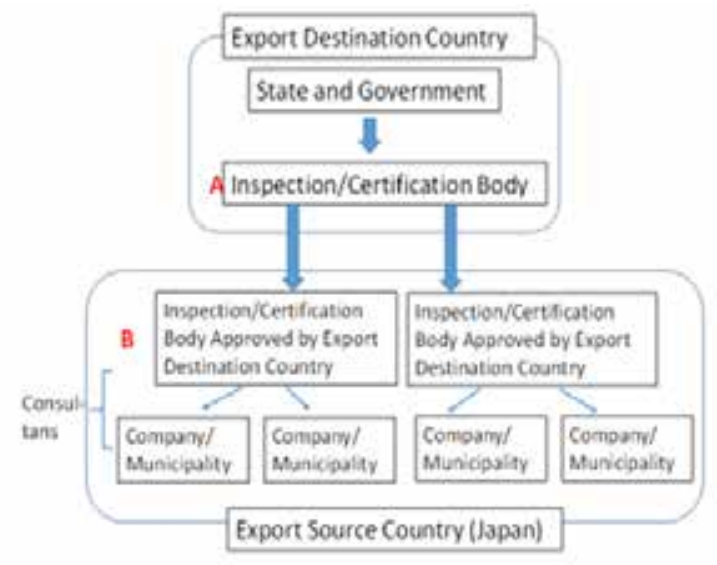
Figure 1. Halal Certification Process in
Japan

Source: (Yamaguchi, 2019) destination country. While the second way is by applying or obtaining certification from institutions in Japan that have been given authority by the certification body in the respective export destination countries. Therefore, the issue of halal certification is one of the big challenges for Japan to penetrate the Muslim market (Zulaikha, 2020).

Companies that attempt to obtain halal certification must comply with the criteria that have been determined by each certification body and renew their certification annually. It is also challenging when the process flow as shown in figure 1 has been passed, where in fact, products that have been certified by foreign bodies are not always accepted in other countries as products that pass halal certification (Yamaguchi, 2019). Therefore, Japanese factories and manufacturers must obtain several certifications according to the requirements of each export destination country.

Nowadays, there are several halal certification authority bodies in Japan as listed in table 3. They oversee the certification of certain items, such as slaughtering food processing and seasoning, with permission from foreign halal authority agencies, including Jakim (Malaysia), MUI (Indonesia), and ESMA (UAE). This is all done by the Japanese government to provide assurance that the Japanese government is serious and tries to meet halal standards as much as possible so as to create trust for the Muslim market.

According to the representatives of Food Diversity Inc. as one of the private sectors that plays a significant role in developing the halal industry in Japan, without a centralized direction, such as a halal certification body, services of restaurants, for example, have to handle everything independently. As a result, it is difficult to maintain a consistent standard of permitted goods and services as restaurants seek certification from different bodies, thus the process of halal certification becomes complicated and increasingly expensive (Zulaikha, 2020).

\section{Japan's Rational Choice in Developing the Halal Industry}

There are reasons that underlie a Muslim-minority country like Japan to develop a halal industry in their country as a rational choice compared to previous times. The emergence of the halal industry in Japan 
MIMBAR, Vol. 37, No. $1^{\text {st }}$ (June, 2021), pp. 187-198

Table 3

Halal Certification Authority Bodies in Japan

\begin{tabular}{|c|c|c|c|c|c|}
\hline Country / Region Body & Malaysia - & & Jonesia - M & & UAE - \\
\hline $\begin{array}{l}\text { Japanese Certificating } \\
\text { Body (Abbreviation) }\end{array}$ & & Slaughter & $\begin{array}{c}\text { Food } \\
\text { Processing }\end{array}$ & Flavoring & \\
\hline $\begin{array}{l}\text { Japanese Muslim } \\
\text { Association (JMA) }\end{array}$ & $\checkmark$ & & $\checkmark$ & $\checkmark$ & \\
\hline $\begin{array}{l}\text { Japan Halal Association } \\
\text { (JHA) }\end{array}$ & $\checkmark$ & & & & $\checkmark$ \\
\hline $\begin{array}{l}\text { Japan Halal Unit } \\
\text { Association (JHUA) }\end{array}$ & $\checkmark$ & & & & \\
\hline Japan Islamic Trust (JIT) & $\checkmark$ & & & & $\checkmark$ \\
\hline $\begin{array}{l}\text { Muslim Professional Japan } \\
\text { Association (MPJA) }\end{array}$ & $\checkmark$ & $\checkmark$ & $\checkmark$ & & \\
\hline $\begin{array}{l}\text { Nippon Asia Halal } \\
\text { Association (NAHA) }\end{array}$ & $\checkmark$ & & & & \\
\hline $\begin{array}{l}\text { Emirates Halal Center } \\
(\mathrm{EHC})\end{array}$ & & & & & $\checkmark$ \\
\hline
\end{tabular}

Source: Arata (2018) in (Yamaguchi, 2019)

is based on reasons for globalization, the fall of Japanese yen, demographic and Japan's bilateral relations with other countries.

\section{Globalization}

The reason that underlies Japan to develop the Halal industry as Japan's rational choice in facing the global market is globalization. The trend of globalization has become a giant pillar of the economy and industry. On the other hand, cultural globalization between religions, ethnicities, and countries is also a phenomenon that deserves attention from the perspective of the global halal industry. Communication technology has driven major and fundamental changes in human life and civilization, among which the conventional geo-political and geographical boundaries have shifted considerably (Dudi, 2001). Globalization means that Japanese citizens should expose themselves, building interaction, entering into social life as individuals, Japanese citizens, and citizens of the world in international community (Deniar \& Effendi, 2019).
Islam started to grow in Japan along with the Meiji restoration era. The growing Muslim population is inseparable from the transmigration of the Turks, Turkmenists, Uzbeks, Tajikistans, Kyrgyzstan, and Kazakhstan. In the 1980s, foreign workers came from Muslim countries such as Bangladesh, Iran, Indonesia and Malaysia, and students from these countries also arrived. As mentioned earlier, globalization is closely related to transmigration. The various background of Muslim people from other countries to entry Japan, whether for work, education or tourism, make them increasingly blend in with Japanese society and become a preference for Japanese government to become a market share for halal industry to develop in the long term.

In Japan, immigration policy and how Japanese people coexist with 'other culture' is important; it is a manifestation of Japanese principle which is famous for its promotion as a tourist-friendly country (Yamaguchi, 2019). This has resulted societal change in Japan which has made Japanese people more 
open, understand, and care about the values held by Muslims. Changes in the behavior of the millennial generation also encourage global players to invest and become part of the global halal industry (Takashima, 2020). There are beliefs to act on the basis of beliefs about the causal structure of the presence of globalization and its manifestations on the development of Muslims in Japan, thus encouraging Japan to develop the halal industry as its rational choice in facing the global market. Halal lifestyle trend spread through globalization and media. This situation has triggered societal changes in Japan, especially regarding the increasing number of Muslims.

The rapid globalization and internationalization of the halal industry can be a catalyst in developing other potential sectors, such as tourism and education (Ali, 2018). This sector is important and highlighted by the Japanese government as an opportunity to boost the economy which ultimately results in profits for Japan.

\section{The Fall of the Japanese Yen}

The fall of Japanese Yen currency in 2011 due to the great earthquake and tsunami that hit Japan caused low cost carrier airlines issued cheap airline tickets. This situation has led to an increase in the number of foreign tourists visiting Japan. According to data released by JNTO (Japan National Tourism Organization), there were about 923,000 tourists visiting Japan in April 2012. This figure has increased from 18.1 percent in previous years, which recorded around 879,000 tourists in July 2010 (Hidayat, 2013).

With the fall of Japanese yen, citizens of other countries are easier and more interested in visiting Japan because the prices are cheaper, so this affects the high number of tourists who come to Japan (Numajiri, 2015). The causal relationship that brings the flow of foreigners, especially Muslims, will lead into different environment. It becomes logical when various backgrounds of foreign nationals enter Japan and create a preference for Japan to change new target markets for Japanese tourism, including the Muslim market. One of the markets for the Japanese halal industry besides Muslim tourists is Japanese Muslims and Muslim foreign students living in Japan. Khadija Takashima as one of the Japanese Muslims admits that the Muslim community in Japan which has continued to grow since the last decade will become a potential market for halal industry. According to her statement, there is a need to increase public awareness about halal products in order to enhance market potential, therefore the development of halal industry will be evenly distributed throughout Japan (Takashima, 2020).

According to the global strategy manager of Halal Media Japan, the Japanese government strongly supports to create conducive environment for the development of halal industry. The Japanese government and private sectors are looking for the opportunities in the midst of their country's limitations, directing their targets towards the east to gain market share for the halal industry. For this reason, they strive to understand and accommodate the needs and convenience of Muslim tourists while in Japan in order to become a Muslim-friendly tourist destination, thus it can further provide benefits for Japan as the final goals of rational choice in developing halal industry (Zulaikha, 2020).

\section{Demographics}

Japan as one of the largest economies in the world has experienced the problem of population aging to an unprecedented degree. More than 20 percent of Japan's population is over the age of 65 , the highest proportion in the world. By 2030, at least one in three people will be 65 years or older, and one in five people over 75. Japan's rapid aging process is striking because of the high rate of economic growth and changes in family and social structures in the post-war period (Walia, 2019).

The declining birth rate in Japan and the increasing elder population have contributed to the slowdown in economic growth over the past few years, causing the Japanese yen to continue to weaken (Numajiri, 2015). This matter triggers the government to search for new methods to overcome the slowdown in economic growth as well as an opportunity for the Japanese government, where limited resources (in this case. an aging population) can pave the way for developing the halal industry in the country in order to improve the country's economic pace.

In this case, the Japanese government has a preference for shifting the target market to a more promising market, specifically the Muslim market to save the country's economy from low consumption due to an increasingly elder population. 


\section{Japan's Bilateral Relations with Other Countries}

In fact, the economic and bilateral relations of a country are closely related, in which the relationship of a country can affect its economic, in this case, Japan's bilateral relations with several partner countries such as China and South Korea. In the last few years the economic slowed down on internal market, especially before 2011. However, Japan was able to survive by exporting products to China that helped balance its economy. Nevertheless, there were numerous issues between these two countries that cause their relationship to become ups and downs.

The conflict between Japan and China regarding the Senkaku/Diaoyu Island for a long time has impacted on dozens of antiJapanese demonstrations throughout China in 2012 (Taylor, 2012). Restaurants and Japanese shopping malls were closed and all Japanese products were banned across China at that time. The number of Chinese tourists coming to Japan has decreased significantly in 2012-2013 (Cuilik, 2017). This situation affected the relationship between the two countries. In addition, since the great earthquake hit Japan in 2011, it was discovered that exports to China have decreased significantly due to radiation problems.

In addition, South Korean tourists also declined significantly at that time due to bilateral relations between Japan and South Korea that had deteriorated again after Japan renewed the claims on Dokdo Island in its latest defense white paper (Utama, 2017). The Dokdo/Takeshima island dispute has strained bilateral relations between Japan and South Korea for decades, even though South Korea is one of Japan's partners in the economic sector (Wiegand, 2015). In addition, Japan and South Korea often clash over the issue of 'comfort women' or South Korean women who were used as sex slaves by the Japanese military during 35 years of colonial governance by Japan, which led to an endless negative of South Korean sentiment towards Japan. The causal structure of Japan's unfavorable relationship with surrounding countries resulted in the slowdown of the Japanese economy. This reason builds the belief that Japan needs to move their target market to other countries in order to stay profitable.

Considering the reasons above, it is not surprising that Japanese Industries shift their target market preferences from neighboring countries to Southeast Asian countries. Southeast Asia is also home to about 240 million Muslims in Southeast Asia, making up about $42 \%$ of Southeast Asia's total population. Southeast Asian countries are becoming an attractive new market opportunity for Japanese Industry.

The strategy that have been made by Japanese government to penetrate the Southeast Asia new market was by applying simplified visa regulations for Malaysia and Indonesia in 2013. This regulation impacted to the number of visitors from Malaysia and Indonesia which had been increased from around 65,000 from each country in 2003 to around 470,000 each and 400,000 in 2018 (Fujita, 2018). The tourism growth was focused mainly on visitors from Malaysia and Indonesia, countries with large Muslim populations (Fujita, 2018). This is the reason that triggered Japanese industry to expand their market target in Halal sector. This sector was not considered as a promising market in the past, but now the Islamic market is considered a profitable business by Japanese industry. Therefore, developing the halal industry in Japan is final action in its rational choice in order to achieve profit.

As a real action for the effort to boost halal industry, Japanese government through the Japan National Tourism Organization (JNTO) has prepared a new travel guide for Muslim visitors that provides general tourist information on mosques, prayer areas and lists of halal restaurants in Japan. Another strategy that have been made by Japanese government in developing halal industry can be seen in table 4, which describes the Japanese government attempt to provide and increase the number and distribution of prayer areas and mosques for Muslim tourists. Table 4 shows that Tokyo as a main tourist area has a large number of prayer areas with total of 58 units, followed by other tourist areas such as Osaka with 19 prayer areas and Kyoto with 18 prayer areas. Even though Japan is a minority country for Muslims, but the number of prayer areas in 2020 is quite large, reaching a total of 294 units.According to the experience of many Muslim students who have lived in Japan for years, Japanese people are generally tolerant with other various religions, including Islam (Febryani, 2020).

With the increasing number of Muslim 
Table 4

Mosques and Prayer Areas in Japan's Big Cities

\begin{tabular}{|c|c|c|c|}
\hline Area & Area for Salat (unit) & Mosques(unit) & Total (unit) \\
\hline Tokyo & 40 & 18 & 58 \\
\hline Osaka & 17 & 2 & 19 \\
\hline Kanagawa & 4 & 3 & 7 \\
\hline Aichi & 6 & 9 & 15 \\
\hline Kyoto & 16 & 2 & 18 \\
\hline Fukuoka & 4 & 1 & 5 \\
\hline Other Location & 102 & 70 & 172 \\
\hline Total & 189 & 105 & 294 \\
\hline
\end{tabular}

visitors, tourist and business associations have intensified efforts to improve services for Muslim tourists. These Muslim-friendly services, such as the increasing number of prayer areas and an increasingly diverse selection of halal food, greatly affect the convenience for Muslim to travelling around Japan (Febryani, 2020).

The seriousness of the Japanese government to develop halal industry in Japan is closely related to the reasons of economic improvement which has triggered a large demand for halal food and other halal services since they aim to increase profits along with the increase of Muslim people who visited Japan as a final purpose of Japan's rational choice.

\section{Conclusion}

The results of this study indicate that halal industry segmentation is well developed in Japan, including halal food, halal restaurant, halal cosmetics, and halal fashion. The development of Japanese halal industry segmentation almost equals with other Muslim majority countries. The reasons for Japan in developing the halal industry as a rational choice for its country in facing the global market as a non-Muslim country with a relatively low Muslim population compared to other large countries in East Asia are based on the globalization era, fall of Japanese yen, demographics, and Japan bilateral relations with neighboring countries. Eventually, these reasons have triggered Japan to take beneficial choices to boost its economy, one of which penetrates the Muslim market by developing halal industry as a form of target market diversion to maintain the existence of the economy in Japan.

The issue of halal certification is one of Japan's major challenges in penetrating the
Muslim market. In order to be able to take part in the global halal industry, Japanese companies have to struggle to obtain halal certification from various countries, especially Muslim-majority countries which have halal certification authorities that have been recognized worldwide, such as JAKIM Malaysia.

\section{References}

Adidaya, Y. A. (2016). Halal in Japan : History, Issues and Problems. June, 1-64.

Akim, A., Konety, N., Purnama, C., \& Korina, L. C. (2019). The Shifting of Halal Certification System in Indonesia: From Society-Centric to StateCentric. MIMBAR : Jurnal Sosial Dan Pembangunan, 35(1), 115-126. https:// doi.org/10.29313/mimbar.v35i1.4223

Ali, H. (2018). Tinjauan Industri Halal Global dan Pariwisata Halal. Retrieved from Islamic Market: https://islamicmarkets. com/articles/overview-of-the-globalhalal-industry-and-halal-tourism-1

Anwar, A. (2019). Taiwan Dorong Industri Wisata Halal. Retrieved from Kabar 24: https://kabar24.bisnis.com/ read/20190923/19/1151585/taiwandorong-industri-wisata-halal

Budianti, N. (2020). Working in Japan as a muslim. (Nurfarah, Interviewer)

Collins, T. (2012). Great East Japan Earthquake: economic and trade impact Economic impact on Japan. Trade Competitiveness \& Advocacy Branch, Austrailia, September 2011, 1-8. https:// dfat.gov.au/news/news/Documents/ great-east-japan-earthquake-economicand-trade-impact.pdf

Cuilik, M. (2017). Effects of the Senkaku/ 
Diaoyu Island Dispute on Sino-Japanese Relations.

Damhuri, E. (2018). Potensi Pasar Halal Cina Capai 1,9 Triliun Dolar AS. Retrieved from Republika.co.id: https:// republika.co.id/berita/ekonomi/syariahekonomi/18/10/30/pheyc7440-potensipasar-halal-cina-capai-19-triliun-dolaras

Deliarnov. (2006). Ekonomi Politik. Jakarta: Penerbit Erlangga.

Deniar, S. M., \& Effendi, T. D. (2019). Halal Food Diplomacy in Japan and South Korea. Journal of Social and Political Sciences, 2(3). https://doi. org/10.31014/aior.1991.02.03.121

Dudi, A. (2001). Perspektif Religius Bagi Eksistensi Masyarakat Muslim Dalam Era Globalisasi. MIMBAR : Jurnal Sosial Dan Pembangunan, 17(No. 4), 355-379.

Febryani, N. (2020). Muslim Student in Japan. (Nurfarah, Interviewer)

Fujita, M. (2018). The Door to Multicultural Coexistence that Halal Initiatives Open. Retrieved from Public Relations Office Government of Japan: https://www. gov-online.go.jp/eng/publicity/book/hlj/ html/201906/201906_04_en.html

Hasan, S., Latif, H., Malik, Y., \& El-Shafaki, R. (2018). State of the Global Islamic Economy Report 2018/19. In Dubai International Finance Centre. https:// haladinar.io/hdn/doc/report2018.pdf

Hasni, N. (2020). Muslim Tourist in Japan. (Nurfarah, Interviewer)

Hidayat, F. (2013). Jatuhnya Nilai Yen Picu Kenaikan Turis ke Jepang. Retrieved from Berita Satu: https://www.beritasatu. com/dunia/115890/jatuhnya-nilai-yenpicu-kenaikan-turis-ke-jepang

Ismail, R. M. (2017). Issues of Japan Halal Industry: An Exploration of Potential Obstacles to Japanese Smesâ Export Development. International Journal of Supply Chain Management, 6(2), 209214.

Kementerian Perencanaan Pembangunan Nasional. (2018). Masterplan Ekonomi Syariah Indonesia 2019-2024. $443 . \quad$ https://knks.go.id/storage/ upload/1573459280-Masterplan Eksyar Preview.pdf

Kitayama, D., Takanokura, M., Ogiya, M., Eksan, S. H. R., \& Ali, M. H. (2018). A study on the halal food supply chain in Japan from an inbound perspective. Lecture Notes in Engineering and Computer Science, 2.
Mathew, V. N., Abdullah, A. M. R. binti A., \& Ismail, S. N. binti M. (2014). Acceptance on Halal Food among Non-Muslim Consumers. Procedia Social and Behavioral Sciences, 121, 262-271. https://doi.org/10.1016/j. sbspro.2014.01.1127

Mohd Nawawi, M. S. A., Abu-Hussin, M. F., Faid, M. S., Pauzi, N., Man, S., \& Mohd Sabri, N. (2019). The emergence of halal food industry in non-Muslim countries: a case study of Thailand. Journal of Islamic Marketing, 11(4), 917-931. https://doi. org/10.1108/JIMA-05-2018-0082

Muhammad Ashfaq. (2018). Global Halal industry: An overview of current developments and future perspectives. Islamic Finance News, December 2018, 20-21.

Murti, T. W. (2017). Halal Life Style And Global Trade. The 7th International Seminar on Tropical Animal Production Contribution of Livestock Production on Food Sovereignty in Tropical Countries, 2, 33-39. https://journal.ugm.ac.id/ istapproceeding/article/view/30115

Muslimah, F. (2016). Inilah Produk Kosmetik Halal dari Negeri Sakura. Retrieved from Go Muslim: https://www.gomuslim. co.id/read/news/2016/07/22/940/inilahproduk-kosmetik-halal-dari-negerisakura.html

Mutiara, S., \& Dian, T. (2019). Halal Food Diplomacy in Japan and South Korea. Journal of Social and Political Sciences, 2(3), 805-813. https://doi. org/10.31014/aior.1991.02.03.121

Numajiri, M. (2015). A Religious Sociological Study of Halal Boom in Japan: Intercultural Understanding Brought by the Religious Taboo. 57-74.

Sah. (2018). Indonesia Diprediksi Masuk Era 'Halal Boom' Tahun Depan. Retrieved from CNN Indonesia: https: //www.cnnindonesia.com/ ekonomi/20180512151436-92-297628/ indonesia-diprediksi-masuk-era-halalboom-tahun-depan

Smith, R. (2017). Modesty is in fashion for Japan's clothing industry. Retrieved from The National News: https:// www.thenationalnews.com/business/ modesty-is-in-fashion-for-japan-sclothing-industry-1.76831

Takashima, K. (2020). Living as a Muslim in Japan. (Nurfarah, Interviewer)

Tanada. (2017). Ever growing Muslim community in the world and Japan. Retrieved from Waseda University: 
https://www.waseda.jp/top/en/ news/53405\#: : : text $=$ The $\% 20$ prevalence $\% 20$ of $\% 20$ Muslims $\% 20$ has,Japanese $\% 20$ Muslims $\% 2$ living $\% 20$ in\%20Japan.

Taylor, A. (2012). Anti-Japan Protest in Cina. Retrieved from The Atlantic: https:// www.theatlantic.com/photo/2012/09/ anti-japan-protests-in-Cina/100370/

Utama, F. (2017). Upaya Diplomasi Publik Korean Selatan Ke Jepang Melalui Korean Wave Tahun 2008-2012. In Universitas Andalas. Universitas Andalas.

Utami, V., Maulida, E., Nurbaeti, E., \& . C. (2019). Muslim Fashion Trends: Analysis and Perspective. KnE Social Sciences, 3(12), 596. https://doi.org/10.18502/ kss.v3i12.4130

Wahidati, L., \& Sarinastiti, E. N. (2018). Perkembangan Wisata Halal Di Jepang. Jurnal Gama Societa, 1(1), 9-19.

Walia, S. (2019). The economic challenge of Japan's aging crisis. Retrieved from Japan Time: https://www.japantimes. co.jp/opinion/2019/11/19/commentary/ japan-commentary/economic-challengejapans-aging-crisis/

Wiegand, K. E. (2015). The South KoreanJapanese security relationship and the Dokdo/Takeshima islets dispute. Pacific Review, 28(3), 347-366. https://doi.org /10.1080/09512748.2015.1011209

Yamaguchi, H. K. (2019). the Potential and Challenge of Halal Foods in Japan. Journal of Asian Rural Studies, 3(1), 1. https:// doi.org/10.20956/jars.v3i1.1712

Yusof, S. M., \& Shutto, N. (2014). The Development of Halal Food Market in Japan: An Exploratory Study. Procedia - Social and Behavioral Sciences, 121(April), 253-261. https://doi. org/10.1016/j.sbspro.2014.01.1126

Zulaikha, N. (2020). Halal Japan Industry. (Nurfarah, Interviewer) 